\title{
Design, construction, monitoring and modelling of Albagés earthdam. A case history
}

\author{
Núria M. Pinyol ${ }^{1,2}$, Eduardo E. Alonso \\ 1- Centre Internacional de Metodes Numerics en Enginyeria (CIMNE), Spain \\ 2- Civil Engineering School, UPC, Barcelona, Spain \\ Corresponding Author's eduardo.alonso@upc.edu \\ nuria.pinyol@upc.edu
}

\begin{abstract}
A zoned earth dam $40 \mathrm{~m}$ high is analyzed and modelled using a numerical code able to deal with unsaturated-saturated soils and the coupled hydro-mechanical phenomena. The paper discusses the selection of the materials for the design of the dam. The dam construction was modelled at the design stage (a type "A" calculation) and results are compared with actual measurements registered during construction until the time when the dam reached two-thirds of the total final height. The limitations of the type A model are discussed and an updated model is presented taking into account compaction data and field tests performed during construction
\end{abstract}

Keywords: earth dam, unsaturated soils, compaction conditions, numerical modelling, real case

\section{INTRODUCTION}

Albagés dam is located in Lleida Province, Catalunya, North-East Spain. It is being completed at the time of writing this paper (June 2017, see Figure 1). The dam is a $90 \mathrm{~m}$ high, zoned earth structure, which serves the purpose of storing water for irrigation of a large area $(50.000 \mathrm{Ha})$ on the left margin of the Ebro Valley. This is a semiarid land having an average rainfall of $400 \mathrm{~mm} /$ year. The dam is built in the valley of a small river (Aranyó) but it is mainly fed by Segarra-Garrigues canal, which brings the water from a dam closer to the Pyrenees mountain range.

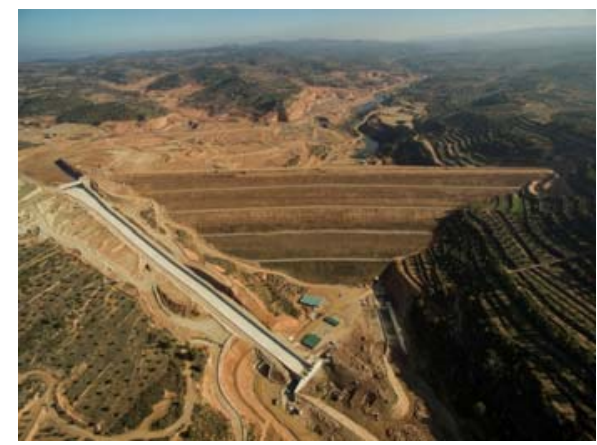

Figure 1. Albagés dam in May 2017.

This paper describes the main issues arising during the design, construction, monitoring and modelling of the dam structure. It covers the period 2002 (at the time of the first site visit) to 2017.

The paper discusses the selection of materials for the different dam zones, their geotechnical properties as determined at the design stage, the data gathered during construction by control and monitoring activities and the process of building a representative finite element model. The model handles the unsaturated-saturated nature of the materials and the coupled phenomena, which explains the generation and dissipation of pore pressures and the associated mechanical behaviour. A particularly interesting aspect of the paper is the comparison of the original 
prediction, before dam construction (a type "A" exercise) with actual measurements and the subsequent changes introduced, in view of the compaction data recorded during construction.

A singular feature of the project was the performance of a trial embankment in 2002-2003, at the design stage, well before the start of the dam construction in 2014. This trial embankment was conceived as a way to overcome the well-known limitation of laboratory tests on small samples to represent geotechnical properties at the real scale. In addition, the trial embankments allowed the investigation of compaction procedures required to attain proper compacted soil properties.

\section{AN OVERVIEW OF AVAILABLE MATERIALS}

In earthdam design, environmental regulations limit in practice the location of construction materials to the area occupied later by the reservoir. The geology of the dam emplacement and the future reservoir was well established because of the abundant rock exposures in road cuts and river valleys (Figure 2). The rock mass shown in these photographs belongs to the Oligocene and is described as a sequence of reddish claystone and sandstone banks horizontally layered. Vertical fractures are observed, especially in the sandstone layers. They facilitate the formation of blocks during excavation in quarries. A more developed system of fractures was also identified at the dam valley bottom during the excavation of dam foundations and the first recordings of water pressures.
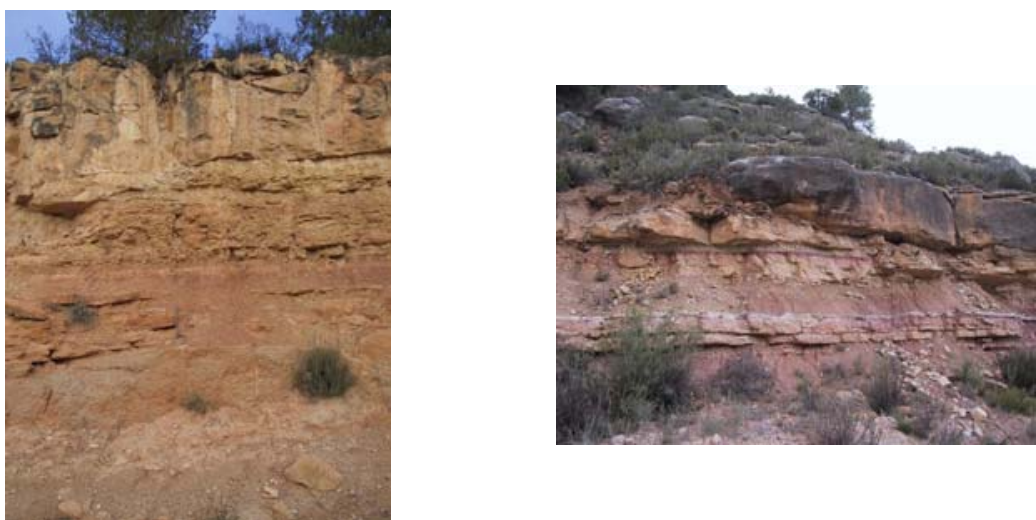

Figure 2. Horizontally layered Oligocene claystone and sandstone banks. Aranyó river valley

Quarry excavations showed the detail of sedimentation layers: A very heterogeneous sequence of claystone of varying cementation, which eventually transforms into soft sandstones banks. The challenge was to design a $90 \mathrm{~m}$ high dam knowing that available materials in a large area around the dam did not experience any significant change from a geological perspective. There was an exception, however: some small valleys were partially filled by fine silty soils resulting from erosion and short-distance transport of the parent Oligocene banks.

Figure 3 shows a backhoe excavation of theses quaternary soils. They turned out to be low plasticity silty clays. They offered the possibility of integrating them in the dam, provided the necessary volume was available (around $1 \mathrm{Mm}^{3}$ ). Field surveys indicated that this volume could be extracted in small tributary valleys located within the reservoir area and this information opened the possibility of designing an homogeneous impervious core. 


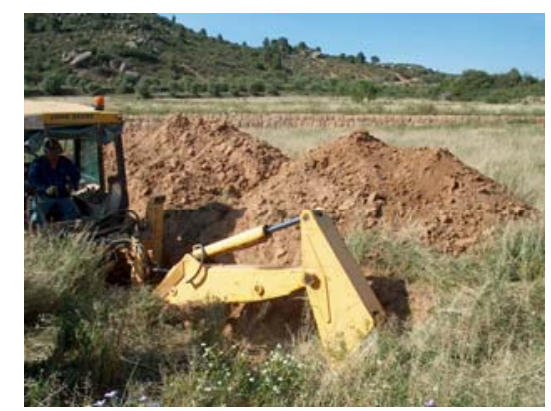

Figure 3. Colluvial quaternary low plasticity silty clay

Back to the Oligocene formation, the cementation of claystone layers had a rapid variation when examined in a direction perpendicular to layering. The heterogeneous nature of the banks, both in mineralogical composition and cementation, posed a question difficult to answer by standard laboratory tests on samples. The question was to predict the overall behaviour of the Oligocene banks when excavated, humidified and compacted by heavy equipment. The answer was to conduct a trial embankment at the design stage. Main observation concerned compaction conditions and their relationship with compaction equipment and energy, compacted soil stiffness and permeability. Two "soils" were tested: the material resulting from the excavation of the Oligocene formation, which was dominated by the reddish clay component and the quaternary silty clay. The first one is named "claystone" in this paper. The objective was to decide a dam cross section, which could meet the necessary safety requirements.

\section{SUMMARY OF MAIN GEOTECHNICAL PROPERTIES. TESTS ON COMPACTED SAMPLES. LABORATORY AND TRIAL EMBANKMENTS}

\subsection{Identification}

The quaternary silty clays are low plasticity materials $\left(\mathrm{w}_{\mathrm{L}}=23-26 \% ; \mathrm{wP}_{\mathrm{P}}=16-18 \%, \mathrm{PI}=5.5-8 \% ; \%<\# 200=60-80 \%\right)$ classified as CL or CL-ML. Main minerals are calcite, dolomite, quartz and illite (mica). This is a well graded material $(\mathrm{CU}>50)$ but it does not compact efficiently because of the low plasticity of its fines.

The claystone, once remoulded, becomes a low plasticity clay $(\mathrm{CL})\left(\mathrm{w}_{\mathrm{L}}=29-34 \%\right.$; $\left.\mathrm{w}_{\mathrm{P}}=18-19 \%, \mathrm{PI}=10.5-15 \%\right)$. The fines content depends markedly on the remoulding action before the grain size analysis. The clay-like material has fines contents in excess of $85 \%$. The mechanical action of quarry excavation and bulldozer spreadout results in a well graded gravel-like material which will undergo further degradation under water action and additional energy input. Main minerals are also calcite, dolomite and quartz but the clay minerals are now more abundant and include illite, mica and chlorite.

\subsection{Permeability}

Field and laboratory permeability values of claystones derived from permeameter and consolidation tests are represented in terms of void ratio in Figure 4. Highest values, in excess of $10^{-7}-10^{-6} \mathrm{~m} / \mathrm{s}$ were measured in field tests for the horizontal permeability. A reasonable correlation of $K$ with void ratio is found if field determinations in trial embankments ("in situ" in the figure) are not included. 


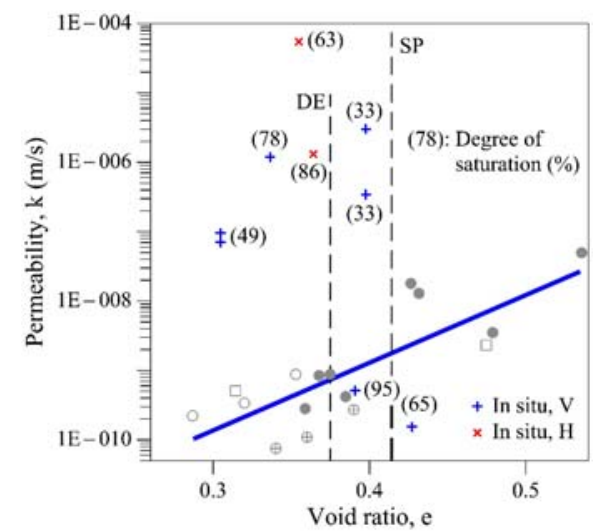

Figure 4. Saturated permeability values of claystone from laboratory and insitu tests.

\subsection{Strength and compressibility}

Figure 5 shows effective cohesion and friction values on silty clay and claystones determined in drained tests. The figure includes data from ring shear, direct shear and triaxial tests. Drained friction angles of compacted claystones samples remain in the range $28 \pm 1^{\circ}$. The minimum measured residual friction is $25.6^{\circ}$. Compacted silty clay exhibited higher friction values $\left(32-33^{\circ}\right)$ in all cases. Measured drained cohesion decrease when saturation incresases and for lower compaction energies.

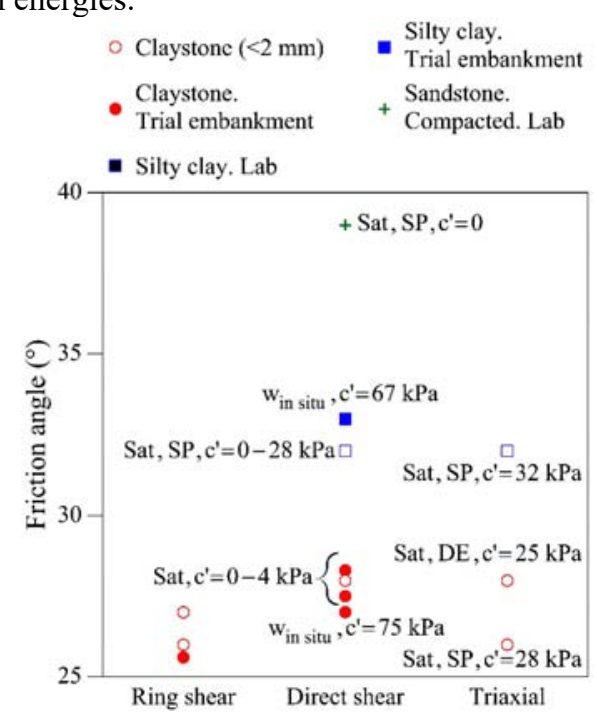

Figure 5. Friction angles and effective cohesion of dam compacted materials, determined on the test types indicated.

Figure 6 shows the stiffness moduli of compacted claystone. The figure includes Young moduli derived from plate loading tests, isotropic and oedometric tests. Results are plotted in terms of void ratio and an indication of the degree of saturation is given. The figure only attempts to provide an approximate information of the stiffness of compacted claystone. Oedometric values tend to be smaller because of the difficulty to measure small deformations. It was expected that the claystone compacted in the dam could reach void ratios in the range 0.35 0.40 and this estimation could result in moduli in excess of $50 \mathrm{MPa}$ for saturated conditions.

Stiffness data for compacted silty clay is given in Figure 7. Expected in situ void ratios for this material could be in the range 0.4-0.45. 


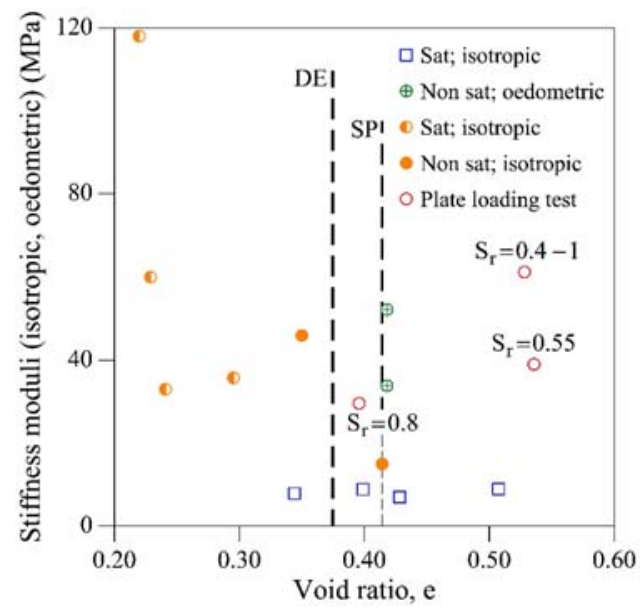

Figure 6. Isotropic and oedometric stiffness moduli of compacted claystone from laboratory and plate loading tests as a function of void ratio.

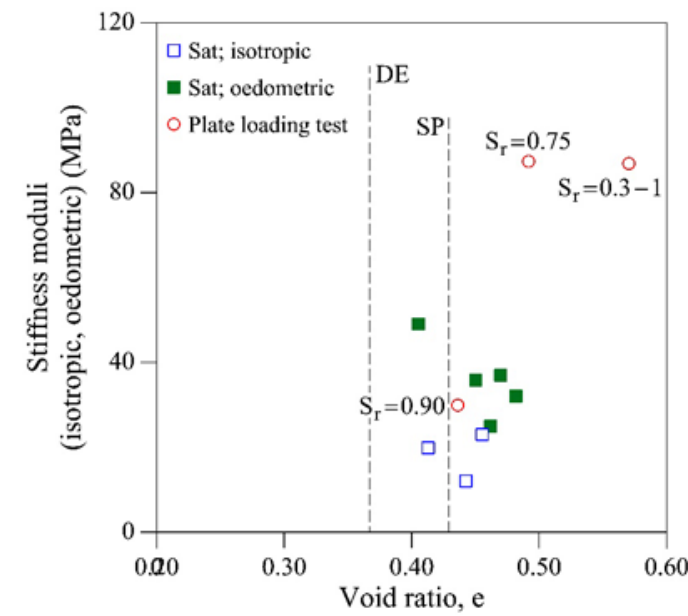

Figure 7. Isotropic and oedometric stiffness moduli of silty clay from laboratory and plate loading tests as a function of void ratio.

\section{CROSS SECTION DESIGN}

The dam was conceived as a zoned earth structure, its stability being guaranteed by two large shoulders made of compacted claystone. A central symmetric core of compacted silty clay provides the impervious barrier. This decision was motivated by the risk of high horizontal permeability of the compacted claystone and the high variability of the source material (layered banks of claystones and sandstone of variable cementation). The quaternary silty clay provided a guarantee of homogeneity. Its low PI was a concern, which could be resolved by adequate filters protecting the core.

Experience gained in trial embankments also revealed the low vertical permeability of compacted claystone because of the remoulding action of compaction equipment on the upper centimetres of the compacted layers. This low permeability could retard the water pressure dissipation of upstream shoulder during rapid drawdown. In addition, the pore water pressure developed during construction and the control of rain-induced pressure in the downstream shoulder could reduce dam safety. These considerations led to the cross section design shown in

Figure 8. A filter/drain blanket, connected with the downstream chimney drain of the core, separates the in situ claystone foundation from the compacted material.

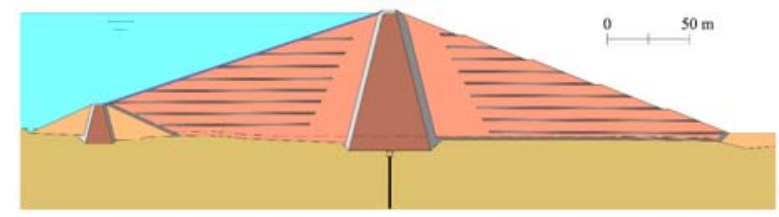

Figure 8. Initial design. Central cross section.

A drainage gallery excavated in the natural rock formation serves to control the effectiveness of the planned injection curtain and the associated drainage. A set of drainage blankets was also designed to facilitate the drainage of the claystone shoulders. This design was completed in 2005.

Dam construction started in 2011 and a more precise evaluation of the availability of the different construction materials was carried out. In general, design predictions were accurate. It was found, however, that the expected volume of sandstone-based filters and drains was difficult to secure at a reasonable cost. Therefore, the design was modified as shown in Figure 9. An upstream rockfill mantle was designed. It occupies part of the original claystone upstream shoulder. In addition, a rockfill foot was added to the downstream shoulder. 


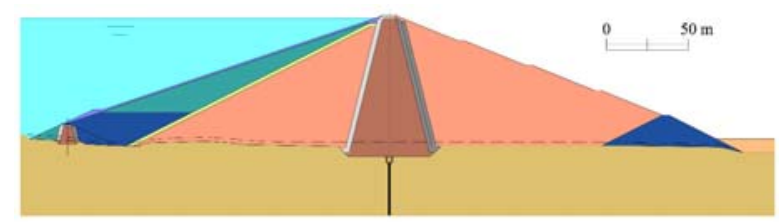

Figure 9. Final design. Central cross section.

Both designs satisfied standard safety criteria summarized in Table 1.

Table 1 Design safety factors for upstream and downstream slopes.

\begin{tabular}{l|c|c}
\hline \hline & No seismic effect & Seismic effect \\
\hline Construction stage & 1.2 & 1.0 \\
\hline Maximum reservoir level & 1.4 & 1.3 \\
\hline Rapid drawdown & 1.3 & 1.0 \\
\hline \hline
\end{tabular}

Recommendations in Table 1 were made in the ancient 1967 "Instruction for the design of large dams" in Spain. No details on how to select strength parameters or calculation procedures were given at that time. Recent recommendations do no mention numerical values for the safety factors and assign the task of calculating safety and the associated geotechnical expertise to the dam designer. The remaining of this paper discusses the performance and modelling of the dam built, which follows the design shown in Figure 9.

\section{CLASS A PREDICTION. COMPARISON WIHT MONITORING DATA}

The available geotechnical information from laboratory tests on samples, information from trial embankments, both from the original design as well as additional field and laboratory tests performed during the development of the modified design are summarized as follows:

a) Optimum compaction conditions

Claystone (shoulders): $\gamma_{\mathrm{d}}=2.1 \mathrm{Mg} / \mathrm{m}^{3}: \mathrm{w}=10 \%$ (Modified Proctor)

Silty clay (core): $\gamma_{\mathrm{d}}=1.98 \mathrm{Mg} / \mathrm{m}^{3}: \mathrm{w}=14 \%$ (Double Energy Proctor)

The Modified Proctor for the claystone and the Double Energy Proctor for the silty clay were adopted as a reference compaction. No risk of soil swelling was expected because of the low plasticity of claystone and silty clay. Therefore, a high compaction density was specified.

b) Strength

Claystone: $c^{\prime}=0, \phi^{\prime}=28^{\circ}$ (saturated material)

Silty clay: $c^{\prime}=0, \phi^{\prime}=31-32^{\circ}$ (saturated material)

c) Permeability for saturated conditions

Claystone: Vertical: $5 \cdot 10^{-6}-10^{-9} \mathrm{~m} / \mathrm{s}$; Horizontal: $5 \cdot 10^{-5}-10^{-8} \mathrm{~m} / \mathrm{s}$

Silty clay: Vertical: $10^{-7}-10^{-9} \mathrm{~m} / \mathrm{s}$; Horizontal: $10^{-6}-10^{-8} \mathrm{~m} / \mathrm{s}$

The specified ranges reflect the variability found when comparing laboratory tests on samples and insitu measurements (falling head permeameters in trial embankments)

d) Deformation moduli

Claystone: $30-120 \mathrm{MPa}$

Silty clay: $40-100 \mathrm{MPa}$

These are ranges for Young or bulk moduli estimated from a variety of sources: laboratory tests (oedometer, triaxial) on compacted samples and plate loading tests performed on trial embankments. The range of values include a variety of origins and conditions (laboratory, field compaction, strain range and the effect of the degree of saturation).

e) Water retention 
The adopted single water retention laws for wetting and drying condition are shown in Figure 10 for the compacted claystone and compacted silty clay. These are relationships found in the laboratory on small size samples. The wetting curves were approximated by means of a Van Genuchten model.
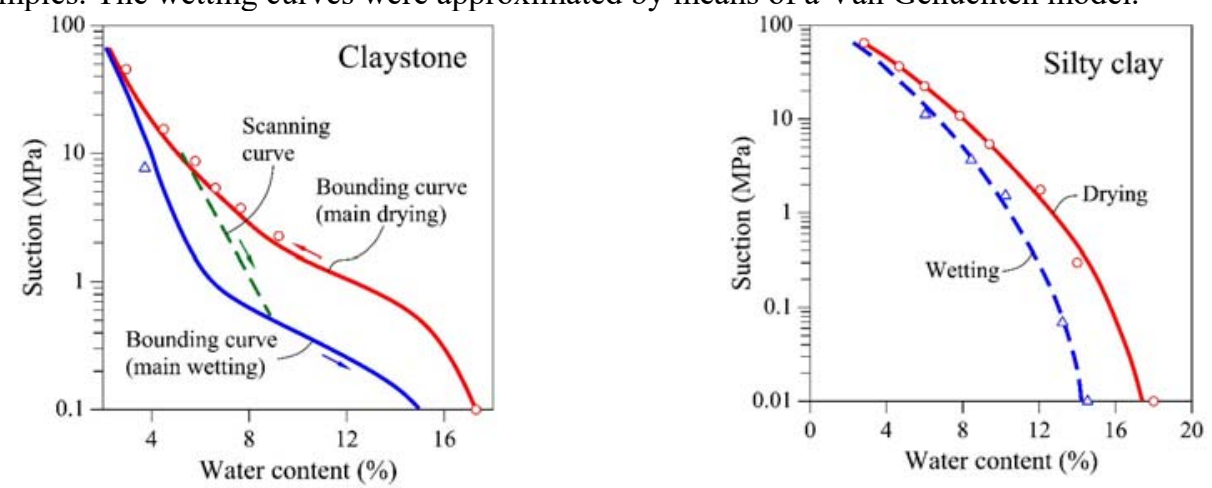

Figure 10. Water retention curves

The finite element program Code_Bright [1] was used for the Class A prediction of Albagés dam construction. The BBM elastoplastic model (Barcelona Basic Model, [2]) describes all the compacted materials. In the past the authors have reported the analysis of several dams by means of a similar simulation technique: Villaveta dam in Navarra, Spain; Beliche dam in southern Portugal [3]; Lechago dam in Aragón, Spain [4]. In comparison with previous cases, what is singular in the case of Albagés dam, besides its maximum height $(90 \mathrm{~m})$ and the limited suitability of available construction materials, is the attempt to perform a successful prediction exercise. Model parameters are to be based on current methodologies at the design stage, which includes a trial embankment, and the subsequent process of refining the model once field control data and monitoring results became available.

Compaction control relies on two classical parameters: dry density and water content. These properties are not included in the formulation of a constitutive model such as BBM, which handles stress-strain related information. However, the dry density could be related with the preconsolidation of field stress simply because increasing the yielding stress implies a parallel increase in density. On the other hand, water content, together with dry density, define the soil suction. Therefore the stress pair $\left(p_{0}^{*}, s\right)$ will describe he compaction state $\left(\gamma_{d}, w\right)$, This discussion is further developed in [5] and [6].

Table 2 Model parameters

\begin{tabular}{l|c|c|c|c|c|c|c|c|c}
\hline \hline \multicolumn{1}{c|}{ Parameter } & Symbol & $\begin{array}{c}\text { Silty } \\
\text { clay } \\
\text { (core) }\end{array}$ & $\begin{array}{c}\text { Claystone } \\
\text { (shoulders) }\end{array}$ & $\begin{array}{c}\text { Sandstone } \\
\text { (rockfill) }\end{array}$ & $\begin{array}{c}\text { Claystone } \\
\text { (foundation) }\end{array}$ & $\begin{array}{c}\text { Sandstone } \\
\text { (foundation) }\end{array}$ & $\begin{array}{c}\text { Drains } \\
\text { and } \\
\text { filters }\end{array}$ & Unit \\
\hline $\begin{array}{l}\text { Young's } \\
\text { modulus }\end{array}$ & $E$ & 50 & 100 & 50 & 500 & 800 & 300 & $\mathrm{MPa}$ \\
\hline Poisson's ratio & $v$ & 0.3 & 0.3 & 0.3 & 0.3 & 0.3 & 0.3 & - \\
\hline $\begin{array}{l}\text { Plastic virgin } \\
\text { compressibility } \\
\text { for saturated } \\
\text { conditions }\end{array}$ & $\lambda(0)-\kappa$ & 0.02 & 0.03 & 0.01 & - & - & 0.01 & - \\
\hline $\begin{array}{l}\text { Parameter } \\
\text { defining } \\
\text { minimum } \\
\text { compressibility } \\
\text { in BBM }\end{array}$ & $r$ & 0.7 & 0.6 & 0.9 & - & - & 0.8 & - \\
\hline $\begin{array}{l}\text { Parameter } \\
\text { defining rate of } \\
\text { increase of }\end{array}$ & $\beta$ & 2 & 2 & 1 & - & - & 2 & $\mathrm{MPa}^{-1}$ \\
\hline \hline
\end{tabular}




\begin{tabular}{|c|c|c|c|c|c|c|c|c|}
\hline $\begin{array}{l}\text { stiffness with } \\
\text { suction in BBM }\end{array}$ & & & & & & & & \\
\hline Reference stress & $p_{c}$ & 0.02 & 0.02 & 0.01 & - & - & 0.02 & $\mathrm{MPa}$ \\
\hline $\begin{array}{l}\text { Slope of critical } \\
\text { state line }\end{array}$ & $M$ & 0.58 & 1 & 1.5 & - & - & 1 & - \\
\hline \multicolumn{9}{|c|}{ Hydraulic parameters } \\
\hline $\begin{array}{l}\text { Saturated } \\
\text { permeability }\end{array}$ & $K_{\text {sat }}$ & $10^{-9}$ & $10^{-9}$ & $10^{-5}$ & $10^{-9}$ & $10^{-5}$ & $10^{-4}$ & $\mathrm{~m} / \mathrm{s}$ \\
\hline Retention curve & $P_{0}$ & 0.5 & 0.8 & 0.01 & 0.5 & 005 & 0.01 & $\mathrm{MPa}$ \\
\hline (Van & $\lambda$ & 0.3 & 0.27 & 0.3 & 0.3 & 0.3 & 0.33 & - \\
\hline Genunchten & $S_{\text {rmax }}$ & 1 & 1 & 1 & 1 & 1 & 1 & - \\
\hline model) & $S_{\text {rmin }}$ & 0 & 0 & 0 & 0 & 0 & 0 & - \\
\hline \multicolumn{9}{|c|}{ Initial state } \\
\hline Void ratio & $e_{0}$ & 0.37 & 0.35 & 0.43 & 0.36 & 0.36 & 0.39 & - \\
\hline Dry density & $\gamma_{d 0}$ & 1.98 & 2.00 & 1.90 & 2 & 2 & 1.95 & $\mathrm{Mg} / \mathrm{m}^{3}$ \\
\hline Water content & $w$ & 12 & 10 & 5 & 13.25 & 13.25 & 23 & $\%$ \\
\hline $\begin{array}{l}\text { Degree of } \\
\text { saturation }\end{array}$ & $S_{\mathrm{r} 0}$ & 0.9 & 0.8 & 0.18 & 1.0 & 1.0 & 0.15 & - \\
\hline
\end{tabular}

The procedure of parameter determination in BBM was discussed in some contributions [7]. Some of the oedometer tests performed on unsaturated compacted samples (loading under constant water content, wetting induced collapse, loading under saturated conditions and unloading) were used for these purposes. Table 2 provides the set of model parameters selected for the prediction of dam behaviour during construction.

\subsection{Model geometry, loading history and sensor location}

Figure 11 shows the finite element model of the central dam section. The foundation was simplified in the manner shown in the figure. Claystone dominates the Oligocene foundation. Two horizontal sandstone banks were defined.

The layers defined in Figure 11 are much thicker than the actual compaction thickness of all materials involved. The layer density was increased in time to simulate the application of dead weight. In this procedure the settlements of the lower level of each new layer is correctly calculated. The continuous plots given below are interpolations of the calculated values for the origin of every new (numerical) layer.

The estimated dam heightening rate imposed in the model was slower than the real construction speed. This difference may explain some discrepancies between model results and measurements.

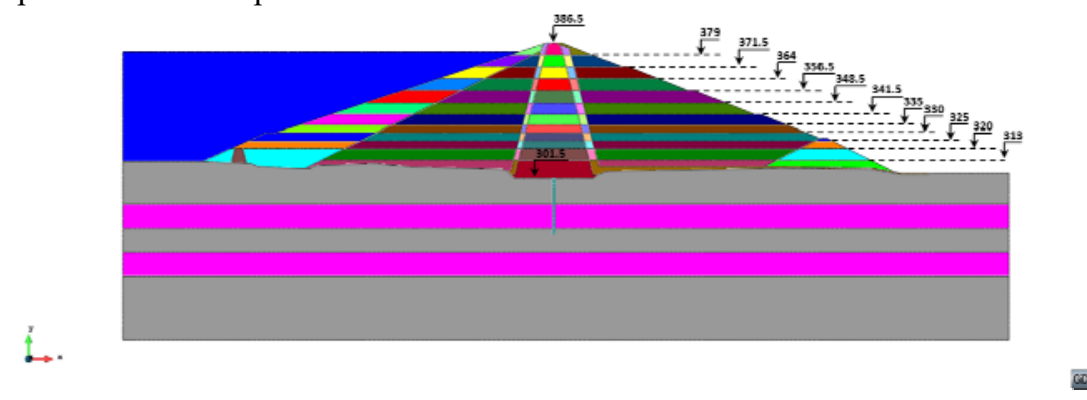

Figure 11. Finite element model

The position of load cells is shown is Figure 12. Their location has two coordinates: the elevation (starting at elevation $274 \mathrm{~m}$ ) and the position in a direction upstream-downstream in a relative scale that goes from 1 to 8 . For instance, sensor CPT-SA0-312-2 means loading cell (CPT), central dam section (SA0), elevation $312 \mathrm{~m}$ and position 2. 


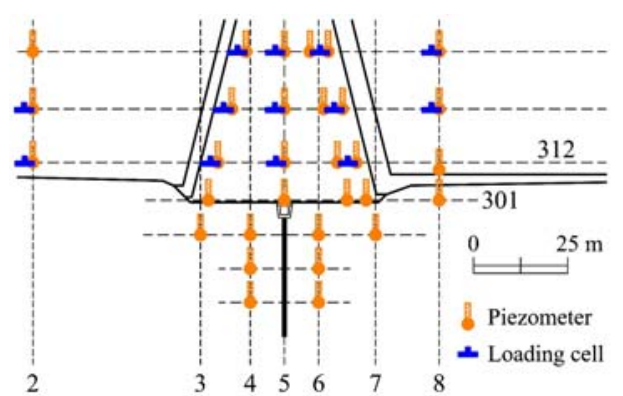

Figure 12. Nomenclature and position of the installed sensors.

\subsection{Results}

\section{a) Total stress}

Figure 13 compares the calculated and measured vertical total stresses at elevation $312 \mathrm{~m}$ when the embankment reaches elevations 320, 335 and $341.5 \mathrm{~m}$. Also shown in the figure is the "static" calculation of vertical stresses as the weight of the soil column above a particular location. The agreement is good in the dam axis and the upstream shoulder. The model captures the interaction between the more deformable core and the more rigid shoulder (and filter layers). Downstream from the dam axis measurements fall below calculated values. This is difficult to explain in view of the essentially symmetric geometry of the dam.

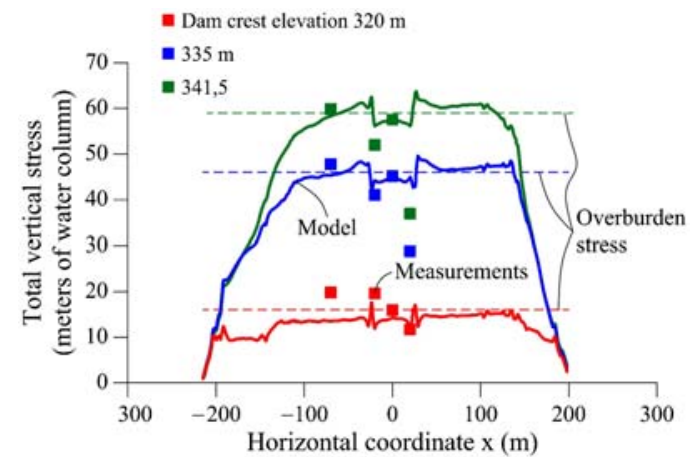

Figure 13. Class A calculation of total stress distribution along a horizontal profile located at elevation 312 compared with measurements for three embankment elevations.

\section{b) Pore water pressure}

The model predicted negative pore water pressures, reducing in absolute value from the "as compacted" estimation, based on water retention curve (Figure 14). However, piezometers installed at elevation 301,305 and 312 recorded positive pore water pressures. Figure 15 shows measurements at elevation $312 \mathrm{~m}$. Measured positive pore water pressure are low if compared with the total stress applied by the height of the embankment.

Discrepancies between model and measurements can be attributed to a wrong selection of the initial degree of saturation of compacted materials but also to errors in the assumed compressibility and permeability of the model materials. Nevertheless, some measured evolutions of the pore pressure (increasing and then decreasing, see Figure 15) are difficult to explain. 

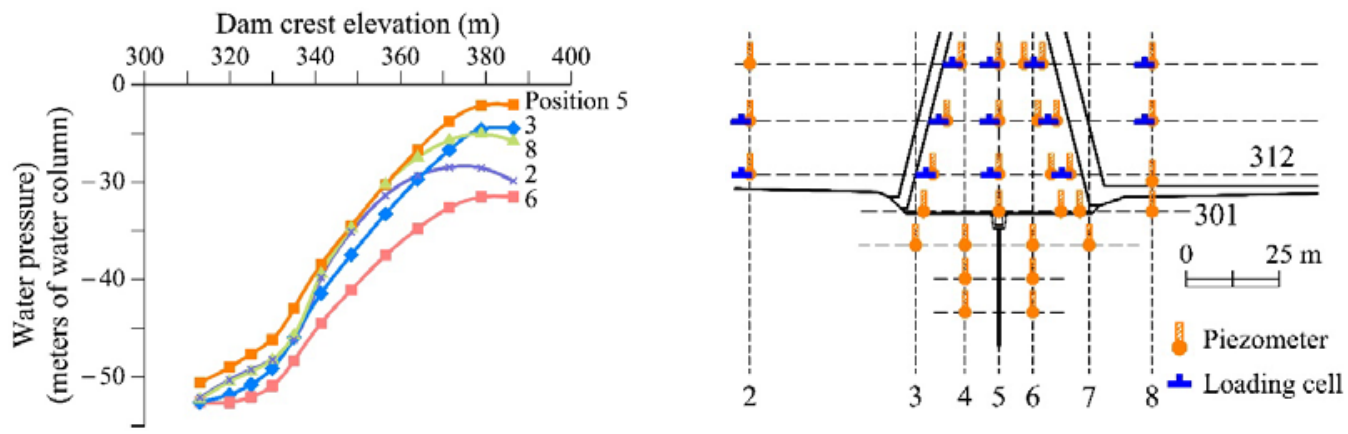

Figure 14. Class A calculated pore water pressure.

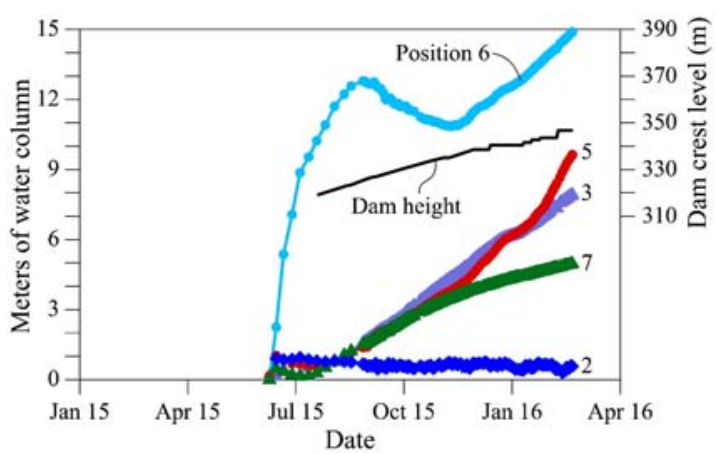

Figure 15. Pore watre pressure measurements.

\section{c) Settlements}

Figure 16 and Figure 17 compare the calculated and measured settlements of the central dam section (SA0-5) and a section downstream (SA0-8), which crossed compacted claystone. The plots provide the settlements for increasing values of dam height. Calculated foundation settlements are much higher than observed. Even if this is accounted for, the model underestimates recorded embankment settlements. Therefore:

- $\quad$ The assumed foundation stiffness was largely underestimated.

- Model fill stiffness overestimated the actual values.

"Model fill stiffness" includes several aspects: Compressibility parameters, the degree of saturation (which largely controls suction) and the assumed preconsolidation stress of compacted materials, which also depends on suction. In addition, given the coupled nature of the deformation phenomena, errors in the estimation of suction or pore water pressure dissipation are also reflected in the evolution of settlements.

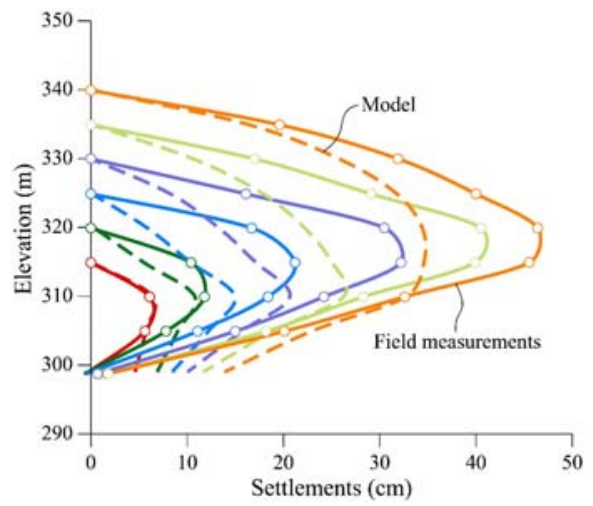

Figure 16. Measured and calculated settlements of central vertical section, $\mathrm{SA0-5}$

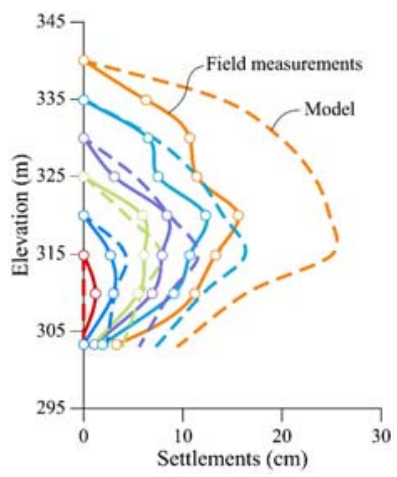

Figure 17. Measured and calculated settlements of vertical section $\mathrm{SA0-8}$ 
It is concluded that the prediction type A was deficient in several aspects. If one accepts that the numerical model is correct, discrepancies should be associated with errors in parameter estimation. A further insight into this difficulty may be gained if the basic data recorded during construction is compared with design specifications. This is discussed in the next chapter.

\section{CONSTRUCTION CONTROL}

A classical and very informative control is the attained dry densities and water contents and its comparison with the reference Proctor values. Figure 18 and Figure 19 provide this information for the silty clay (core) and the claystone (shoulder). Silty clay compaction water contents are systematically $2 \%-4 \%$ above the SP and $2 \times \mathrm{SP}$ Optimum values determined in the laboratory during the design period. Dry densities span a large range: 1.8-1.95 $\mathrm{Mg} / \mathrm{m}^{3}$, centered around the SP optimum. Note also that the water content was high at the start of construction, decreased at intermediate elevation and increased again above elevation 325 . It was found that the silty material was difficult to compact "in situ". The original specification was to take MP energy as a construction reference. The purpose of this specification was to build an impervious and dense barrier. In practice, the reference dry density became the SP Optimum and the water content was systematically larger than the optimum value ( $\mathrm{w}_{\mathrm{opt}}$ ).

The claystone shoulders offered an opposite experience. This material was compacted above MP Optimum density without difficulty. In parallel, compaction water content remained below $\mathrm{w}_{\mathrm{opt}}$. The exception was the first layers compacted at elevation 310-312 m, whose dry density dropped below SP optimum.

Compaction field data for the first $30 \mathrm{~m}$ of embankment are shown in Table 3 . This table is to be compared with the initial state for the Class A prediction (Table 2). Discrepancies are not large for the silty clay core. However, the achieved density in situ was lower $\left(0.1 \mathrm{Mg} / \mathrm{m}^{3}\right)$ than expected. A significant change was found for the claystone, which was compacted to low void ratios. In addition, the degree of saturation was high. The pair $\left(\gamma_{d 0}, w_{0}\right)$ for this material remained close to the saturation line. The sandstone rockfill was also found to compact to high densities because of the substantial breakage of the rock particles during compaction. In terms of mechanical parameters, the dense shoulder will be stiffer than expected. Shoulders are also capable of developing positive pore water pressure because of the high initial degree of saturation. The lower than designed density of the core and its high water content will justify the developments of positive pore pressure during construction and a certain "silo effect" of vertical stresses already mentioned when showing the load cell measurements.
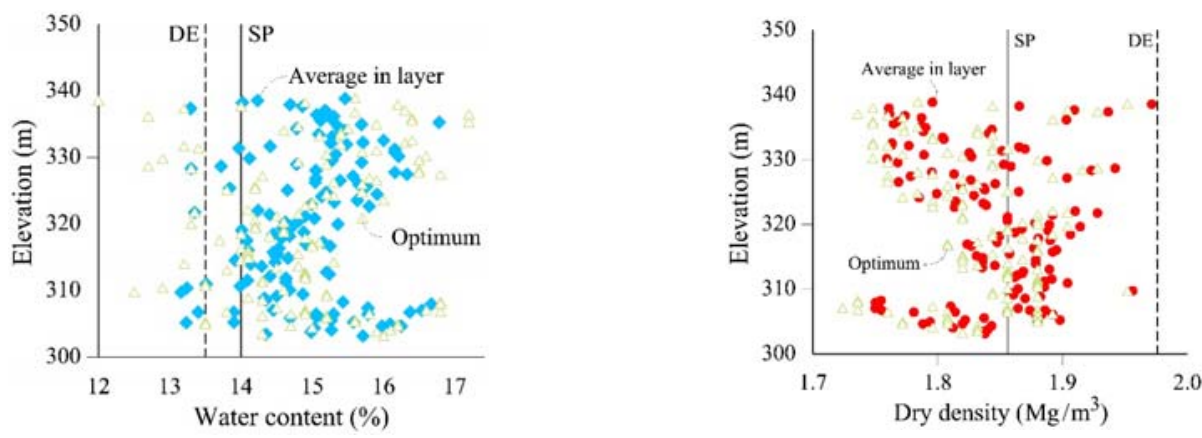

Figure 18. Insitu measurements of water content and dry density from silty clay compaction layers of the dam core. Proctor reference values of the original project are also indicated. 

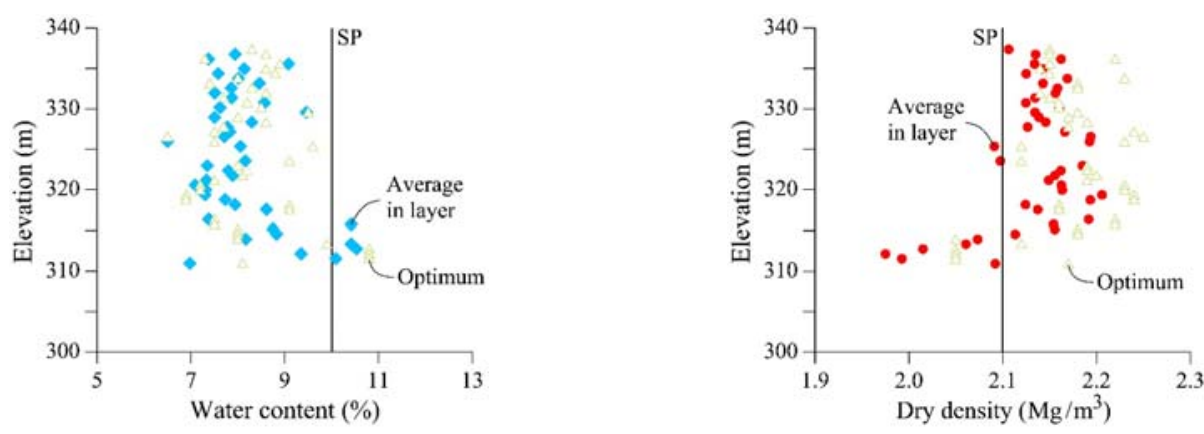

Figure 19. Insitu measurements of water content and dry density from claystone compaction layers of the claystone shoulders. Proctor reference values of the original project are also indicated.

Table 3 Average compaction data. Dam elevation 310-340.

\begin{tabular}{c|l|c|c|c|c}
\hline \hline Initial state & $\begin{array}{c}\text { Silty clay } \\
\text { (core) }\end{array}$ & $\begin{array}{c}\text { Claystone } \\
\text { (shoulder) }\end{array}$ & $\begin{array}{c}\text { Sandstone } \\
\text { (rockfill) }\end{array}$ & $\begin{array}{c}\text { Drains and } \\
\text { filters }\end{array}$ & Unit \\
\hline$e_{0}$ & $0.43-0.47$ & 0.27 & 0.31 & 0.43 & - \\
\hline$\gamma_{d 0}$ & $1.85-1.90$ & 2.15 & 20.8 & 1.90 & $\mathrm{Mg} / \mathrm{m}^{3}$ \\
\hline$S_{0}$ & $0.89-0.95$ & 0.87 & 0.61 & 0.23 & - \\
\hline$w_{0}$ & $14.5-15.5$ & 8.5 & 6.9 & 3.6 & $\%$ \\
\hline \hline
\end{tabular}

\subsection{Updated parameters}

a) Compressibility

The most relevant new information came from plate loading tests performed on the embankment in which loading-unloading cycles were applied. BBM compressibility parameters were estimated from the settlementloading curves obtained in the tests taking into account the expression for the settlement of a rigid plate on an elastic half space. An average stress of the test was considered to transform $E$ values into the non-linear modulus used in BBM, as well as the void ratio and water content of the soil, also measured during the test.

\section{b) Other}

In two of the plate loading tests performed on the clayey core a change in compressibility was noticed for a vertical stress of $0.1 \mathrm{MPa}$ (equivalent to $\mathrm{p}=0.66 \mathrm{MPa}$ if $\mathrm{K}_{0}=0.5$ ). In other tests, no change in deformation trend was identified. This limited data suggests a low preconsolidation stress due to compaction. A uniform value $p_{0}^{*}=0.06 \mathrm{MPa}$ was adopted for the updated model.

Permeability coefficients reported for the initial model were maintained. A field permeability test following the procedure described in [8] was run on the compacted upstream sandstone rockfill. The estimated permeability $\left(10^{-4} \mathrm{~m} / \mathrm{s}\right)$ was adopted in the calculation model.

\section{UPDATED MODEL PREDICTIONS. COMPARISON WITH MONITORING DATA}

The updated set of constitutive parameters is given in Table 4. A comparison with Table 2 provides a good information of the changes introduced.

Model geometry and the sequence of layer construction was maintained. Construction times were adjusted to reality.

Table 4 Updated model parameters

\begin{tabular}{c|c|c|c|c|c|c|c|c|c}
\hline \hline Parameter & Symbol & $\begin{array}{c}\text { Silty clay } \\
\text { (core) }\end{array}$ & $\begin{array}{c}\text { Claystone } \\
\text { (shoulders) }\end{array}$ & $\begin{array}{c}\text { Sandstone } \\
\text { (rockfill) }\end{array}$ & $\begin{array}{c}\text { Drain and } \\
\text { filters }\end{array}$ & $\begin{array}{c}\text { Claystone } \\
\text { (foundation) }\end{array}$ & $\begin{array}{c}\text { Sandstone } \\
\text { (foundation) }\end{array}$ & $\begin{array}{l}\text { Units } \\
\text { Comments and } \\
\text { available data } \\
\text { considered }\end{array}$ \\
\hline Young modulus & $E$ & 24 & 95 & 161 & 100 & 10000 & 10000 & MPa & $\begin{array}{l}\text { Loading plate tests and } \\
\text { laboratory test }\end{array}$ \\
\hline Poisson's coefficient & $v$ & 0.3 & 0.3 & 0.3 & 0.3 & 0.3 & 0.3 & - & $\begin{array}{l}\text { Values generally } \\
\text { accepted }\end{array}$ \\
\hline Elastic compressibility & $\kappa$ & 0.02 & 0.002 & 0.001 & 0.002 & - & - & - & Loading plate tests and \\
\hline \hline
\end{tabular}




\begin{tabular}{|c|c|c|c|c|c|c|c|c|c|}
\hline parameter & & & & & & & & & laboratory tests \\
\hline $\begin{array}{c}\text { Plastic compressibility } \\
\text { parameter for saturated } \\
\text { states }\end{array}$ & $\lambda(0)$ & 0.03 & 0.007 & 0.009 & 0.01 & - & - & - & $\begin{array}{l}\text { Loading plate tests and } \\
\text { laboratory tests }\end{array}$ \\
\hline BBM parameter & $\beta$ & 2 & 2 & 1 & 2 & - & - & $\mathrm{MPa}$ & Estimated \\
\hline Reference stress & $p_{c}$ & 0.02 & 0.02 & 0.01 & 0.02 & - & - & $\mathrm{MPa}$ & Estimated \\
\hline $\begin{array}{r}\text { Permeability for } \\
\text { saturated states }\end{array}$ & $K$ & $10-9$ & $10-9$ & $10-5$ & $10-4$ & $10-8$ & $10-5$ & $\mathrm{~m} / \mathrm{s}$ & $\begin{array}{l}\text { Laboratory and insitu } \\
\text { tests }\end{array}$ \\
\hline
\end{tabular}

\subsection{Results}

\section{a) Total stresses}

Figure 20 show a comparison of calculated and measured vertical stresses at elevation 312 and 325 . The updated model predicts a sharper stress transitions when crossing from the core to the shoulders. This is a consequence of the increased deformability of the core because of the lower dry density achieved if compared with initial estimations.

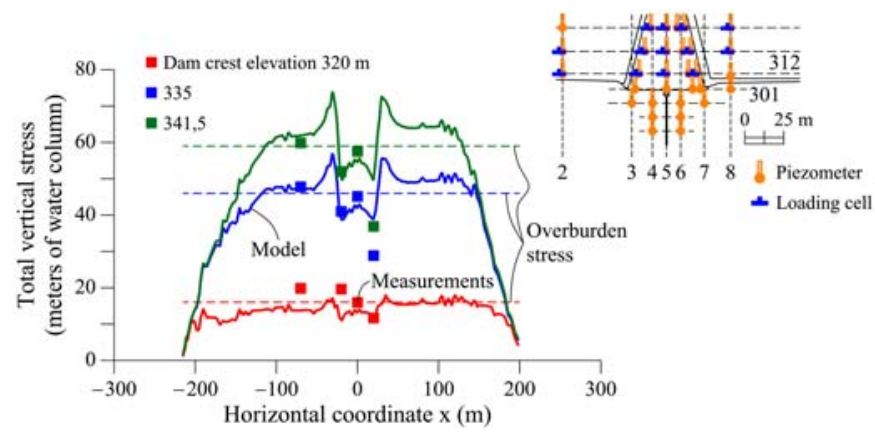

Figure 20. Updated calculation of total stress distribution along a horizontal profile located at elevation 312 compared with measurements for three embankment elevations.

\section{b) Pore pressures}

Figure 22 shows the evolution of pore pressure at elevation 312. The model predicts the development of positive pore pressure when the embankment reached elevation 350 approximately. Piezometers recorded zero or positive pore pressure since the start of observations. This is attributed to water inflow from the foundation, not accounted for in the model, which starts at the unsaturated state after compaction.

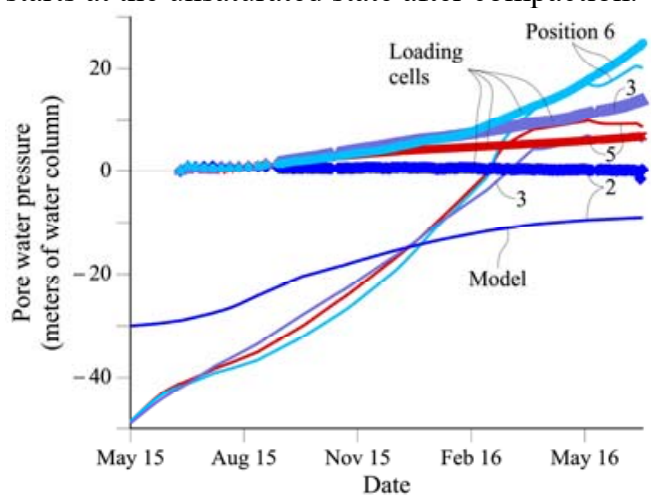


Figure 21. Measured and calculated pore water pressures in the positions indicated at elevation 312.

\section{c) Settlements}

The better identification of compressibility of the different compacted materials and the foundation rock allowed a good agreement between calculations and measurements. This is shown in Figure 22 for two vertical profiles: the vertical profile (SA08) at the center of the dam, maximum height, and the downstream profile (SA08). Also shown are results for SA05 located entirely in claystone, also in the central cross section. The agreement model-measurements is good in the case of the central section. Settlements measured at the downstream location are unexpectedly large when the dam reached $350 \mathrm{~m}$ of elevation.

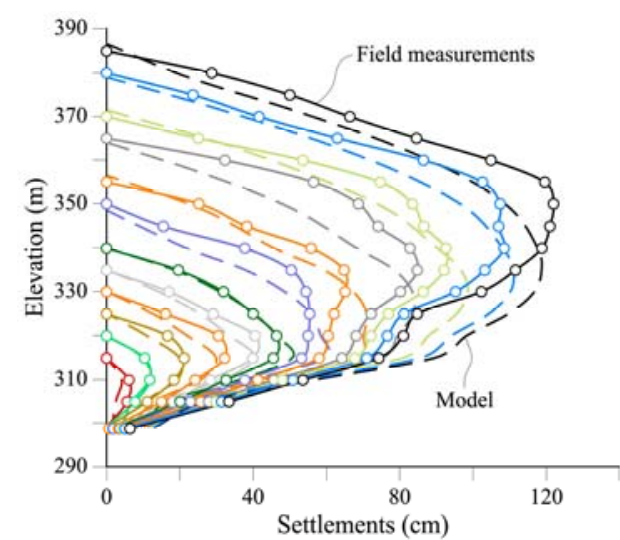

(a)

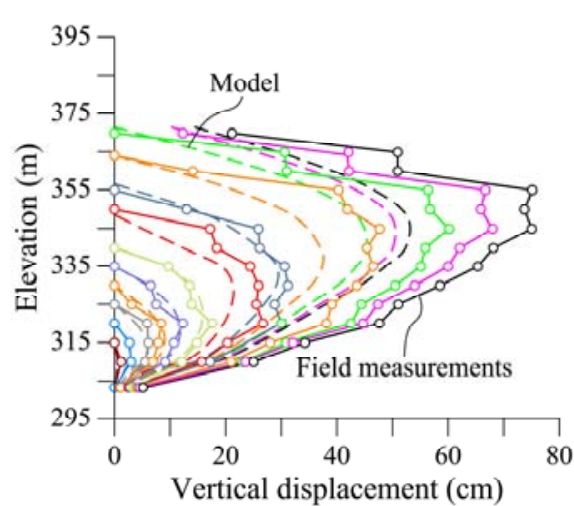

(b)

Figure 22. Updated calculation of vertical displacements and comparison with measurements. (a) central and (b) downstream section.

\section{CONCLUSIONS}

This paper describes geotechnical aspects of a zoned earthdam, $90 \mathrm{~m}$ high, and covers the dam design criteria, construction data as well as modelling results using an elastoplastic model for compacted soils. The emphasis of the paper focusses on the difficulty to characterize the behaviour of the involved compacted materials and evaluates the calculated response against field monitoring data. The analysis presented shows that such difficulties are present even when significant data on geotechnical properties is available. Tests on samples compacted in laboratory and in the trial embankments were carried out as well as field tests.

A class A modelling is firstly presented using a hydro-mechanical coupled numerical code for modelling the soil behaviour for unsaturated conditions. The model was later calibrated once the dam reached a reasonable height (40 $\mathrm{m}$ in the central section) taking into account field compaction data and additional field tests. The model prediction was then compared with monitoring data in terms of stress, pore pressure and settlements. The model and, in particular, the constitutive representation of dam zones, is capable of reproducing main aspects of the dam performance, measured by a reasonably complete instrumentation.

\section{ACKNOWLEDGEMENTS}

The first author acknowledges the financial support to CIMNE by the CERCA Programme/Generalitat de Catalunya and the fellowship IJCI-2015-26342 from the Spanish government.

\section{REFERENCES}

1. S. Olivella, S., Gens, A., Carrera, J. and Alonso, E.E. ()1996 "Numerical formulation for a simulator (CODE_BRIGHT) for the coupled analysis of saline media," Eng. Comput., vol. 13, no. 7, pp. 87-112

2. Alonso, E. E.; Gens, A.; Josa, A. (1990) "A constitutive model for partially saturated soils," Géotechnique, vol. 40, no. 3, pp. 405-430

3. Alonso, E.E., Olivella, S. and Pinyol, N.M. (2005) “A review of Beliche Dam,” Geotechnique, vol. 55, 
no. 4 , pp. 267-285

4. Alonso, E.E., Olivella, S., Soriano, A., Pinyol, N.M. and Esteban, F.. (2011) "Modelling the response of Lechago earth and rockfill dam," Géotechnique, vol. 61, no. 5, pp. 387-407

5. Alonso, E.E.and Pinyol, N.M. (2008) "Unsaturated soil mechanics in earth and rockfill dam engineering.," in Unsaturated soils: Advances in geo-engineering. Vol.1., D. G. and S. J. W. D. G. Toll, C. E. Augarde, Ed. pp. 2-31.

6. Alonso, E.E.and Pinyol, N.M. and Gens, A. (2013) "Compacted soil behaviour: initial state, structure and constitutive modelling," Géotechnique, vol. 63, no. 6, pp. 463-478

7. Gallipoli, D., Onza, F.D., and Wheeler, S.J. (2010) "A sequential method for selecting parameter values in the Barcelona basic model," vol. 1186, pp. 1175-1186

8. Matsuo, S., Hanmachi, S. and Akai. K. (1953) "A field determination of peremeability," in Proceeding of the 3rd International Conference on Soil Mechanics and Foundation Engineering, Vol. 1, pp. 268271. 